\title{
Human-elephant conflict in the buffer zone of Chitwan National Park, Nepal
}

\author{
Deepa Dangol $^{1,2}$ (i) $\mid$ Anuj Ghimire ${ }^{3 *}$ (iD $\mid$ Salina Banskota Bhattarai ${ }^{2}$ (D) \\ ${ }^{1}$ Central Department of Zoology, Institute of Science and Technology, Tribhuvan University, Kathmandu, Nepal \\ 2 Department of Zoology, Tri-Chandra Multiple Campus, Kathmandu, Nepal \\ ${ }^{3}$ Department of Biological Sciences, North Dakota State University, Fargo, U.S.A \\ *Correspondence: anujghimire1@gmail.com
}

Received: 27 June 2020 | Revised: 02 August 2020 | Accepted: 02 August 2020

\begin{abstract}
The interaction between human and wildlife sharing same resources often result negative outcomes and are referred as the human wildlife conflict which affects not only humans but also the wild species. Such conflicts, especially from the mega-herbivores such as elephants has become one of the major management challenges for the Chitwan National Park (CNP), Nepal. Spatial and temporal patterns of human elephant conflict (HEC) in the buffer zone of CNP were analyzed using park data and questionnaire survey conducted among three hundred and ninety residents of thirteen buffer zone user committees (BZUC) within Chitwan district from October 2016 to May 2017. Five hundred and forty-three HEC incidents including three human deaths and two human injuries were reported in BZUC from January 2013 to April 2017. Crop damage was found to be the most common type of damage caused by elephants and were higher during post-monsoon. Property damage incidents were higher during the winter season. There was a negative association between the number of HEC incidents and distance from the forest edge of the national park. However, no significant relation of HEC incidents was observed with average monthly temperature and rainfall. Despite of increasing HEC incidents, majority of people $(77 \%)$ had positive attitude towards elephant conservation and considered elephants as nation's treasure.
\end{abstract}

Keywords: Crop damage, Elephas maximus, Human casualty, Perception, Seasonal pattern

\section{1 | Introduction}

Human-Wildlife Conflict (HWC) is defined as any interaction between humans and wildlife that results in negative impacts on the social, economic or cultural life of humans that ultimately affect on the conservation of wildlife populations, or the environment (WWF 2005). HWC occurs when both the human and wild species compete for the same habitat and resources (Hoare 2000, WWF 2005). Humans suffer economically, socially, culturally and in severe cases, human casualties occur. This affects conservation policies of wildlife population and can lead to displacement or elimination of wild animals, causing further decline in their number, hence, leading to local extinction (Hoare 2000, WWF 2005). HWC is in rising trend all over the world and has become a critical threat to the conflict causing species; especially endangered species such as Asian lion (Panthera leo persica), and tigers (Panthera tigris tigris and P. t. sumatrae) (Distefano 2005, Nyhus 2016). One of the species on thin ice for extinction is the Asian elephant (Elephas maximus) (Choudhury et al. 2008, Goswami et al. 2014).

Elephants are the mega-herbivores that have an important ecological role as ecosystem engineers through altering vegetation, seed dispersal and habitat transformation (Kerley et al. 2008, Campos-Arceiz \& Blake 2011, Haynes 2012). Despite their ecological roles, they are at extreme threat due to habitat loss and fragmentation, poaching for ivory, trophy hunting, etc. (Barnes 1996, Sukumar 2006). Escalating human-elephant conflict (HEC) is another major threat to the elephants, putting them at risk of local extinction in some localities (Hoare 2000, Sukumar 2006, Pradhan et al. 2011). HEC occurs in Asia as well as Africa whenever humans and elephant coincide each other's area while competing for the same resources (Hoare 2000). It continues until people encroach elephant habitat and grow crops near a forest that attract elephants (Barnes 2008, Perera 2009, Fernando and Pastorini 2011, Pradhan et al. 2011). Change in landscape pattern and fragmentation of habitat contracts elephant 
territory that further increases the conflict (Sukumar 2006). Annually million dollars' worth crop and property are damaged and at the same time, hundreds of people and elephants are killed as a result of conflict (Sukumar 2006). HEC not only affects humans economically but also socio-culturally and moreover psychologically; for example, people are less willing to marry their daughters to HEC affected areas due to hardship they suffer (Dhakal \& Thapa 2019, Stone et al. 2019, Prakash et al. 2020). The lowland terai area of Nepal is one of the habitats of fragmented population of the Asian elephants where HEC incidents have been reported frequently. The rate of HEC incidents is increasing in Nepal due to habitat fragmentation and an increase in elephant population migrating from India (Shrestha 2007, Pradhan et al. 2011, Pant et al. 2016). HEC incidents are not uniformly distributed in Nepal. It is comparatively less in central lowland Nepal due to a small population (25-30 individuals) of wild elephants remaining within the protected areas of Chitwan National Park and Parsa National Park (Pradhan et al. 2011). However, the conflict is increasing in recent years (Silwal et al. 2016). Several mitigation measures have been implemented to reduce HEC incidents but none of them is effective in long-term (Perera 2009, Fernando et al. 2011). Hence, HEC has become the foremost, widely debatable conservation issue and challenge for government, policymakers, conservationist and local people of Asia and Africa including Nepal (Sitati et al. 2003, Sukumar 2006, DNPWC 2009).
HEC has been one of the major problems for wildlife conservation and management in Chitwan National Park. Knowledge of the spatial and temporal pattern of conflicts would be important to formulate the management strategies. Therefore, we aimed to explore- i) the nature of HEC in the buffer zone of CNP, ii) spatial and temporal pattern of HEC, and iii) perception of the local residents towards elephant conservation.

\section{2 | Materials and methods}

\section{1 | Study area}

Chitwan National Park (CNP), the first national park of Nepal, designated in 1973, is located at the southern part of central Nepal, covering an area of $952.63 \mathrm{~km}^{2}$ (CNP 2020). It is an example of last surviving ecosystem of terai providing habitat for 68 species of mammals, 546 bird species, 47 species of reptiles, 55 species of amphibians and 126 fish species (DNPWC 2019, CNP 2020). Human population of over 273,977 are living in the buffer zone of CNP (DNPWC 2019). The growing population is highly dependent upon the forest, exploiting its resources. The buffer zone of CNP extends over Chitwan, Nawalpur, Parsa and Makwanpur districts, covering an area of $729.37 \mathrm{~km}^{2}$ (DNPWC 2019). There are 21 buffer zone user committees (BZUC), 1 subcommittee and 1780 user groups under the buffer zone management committee (BZMC) (DNPWC 2019). This study was conducted in the 13 out of 21 BZUCs of CNP (Fig. 1).

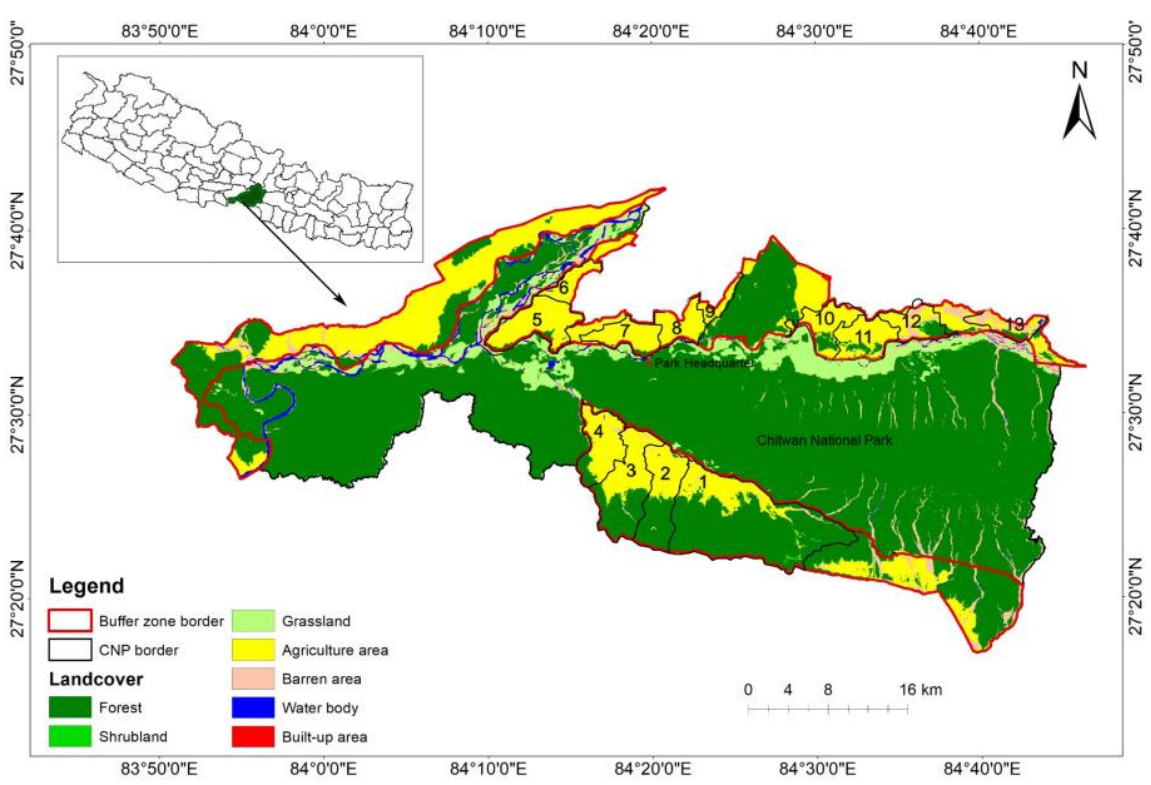

Figure 1. Map of the study area showing the land use pattern in the CNP and its buffer zone (Source: ICIMOD 2013). The numbers indicate the 13 BZUCs within Chitwan district surveyed during this study. 1 : Ayodhyapuri, 2: Rewa, 3: Bagauda, 4: Paanch Pandav, 5: Meghauli, 6: Kalabanzar, 7: Kerunga, 8: Patihani, 9: Barandabahar, 10: Mirgakung, 11: Budhi Rapti, 12: Khagendramalli, and, 13: Kathar.

\section{2 | Data collection}

Primary data were collected via questionnaire survey and key informant interview from October 2016 to May 2017 among the residents of the selected BZUCs. A start point (house) was selected randomly and moved forward in an interval of four houses, selecting the fifth one. In absence of owner or denial for interview, adjacent house was chosen. The head of the house was interviewed but in his/her absence any willing family member was interviewed. A total of 390 households were surveyed that included thirty households from each selected BZUCs (13 out of 21) (Fig. 1). Among 390 respondents, 218 (56\%) were female and $172(44 \%)$ were male. 
Semi-structured interview regarding trend and pattern of HEC and compensation scheme was conducted with 17 key informants. Among them 13 were BZUC representatives, 2 park managers and 2 nature guides. Data on the conflict incidents from January 2013 to April 2017 were collected from the office records of CNP and respective BZUCs.

\section{3 | Data analysis}

The damage caused by elephants was broadly categorized as crop damage, property damage and human casualty. The data collection was done till April 2017 and data analysis has been carried out from the records till April of that year. The trend of HEC incidents over years and variation of conflict incidents with season were tested using Chi-square test. Approximate distance of the HEC incident from the nearest park edge was recorded and the data were grouped at the interval of one kilometer $(0-1$ $\mathrm{km}, 1-2 \mathrm{~km}, 2-3 \mathrm{~km}$ and so on). In order to establish the relationship between the number of conflict incidents with environmental variables, regression analysis was performed between number of HEC incidents and i) the distance of the respective settlement from the nearest forest ii) average monthly temperature, and iii) average monthly rainfall. Average temperature and average rainfall data were extracted from the website of climate-data.org, Bharatpur (https://en.climatedata.org/asia/nepal/central-development-region/bharatpur-

47499/). Analysis of Variance (ANOVA) was conducted to assess significance of variation in i) Human-elephant conflict incidents in various BZUCs over time, and ii) perception between the HEC victim and non-victim respondents. Microsoft Excel 2019 and R v.3.6.1 (R Core Team 2019) were used for statistical analysis.

\section{3 | Results}

\section{1 | Nature of human elephant conflict}

There were 543 incidents of human-elephant conflict reported in BZUCs of the CNP from January 2013 to April 2017. Crop damage $(70 \%)$ was the most common type of damage reported, followed by property damage $(29 \%)$ and human casualty $(1 \%)$. The questionnaire survey revealed that $29.5 \%(n=115)$ of the respondents $(n=390)$ were the victims of HEC in between 2013 and 2017. Similar to the reported cases in BZUCs, crop damage $(80 \%)$ was the most dominant conflict followed by property damage (19\%) and human casualty (1\%). The most raided crops were paddy, maize, wheat, mustard and banana. Three human deaths, one in 2014 and two in 2016; and two additional human injuries in the year 2016 were reported.

\section{2 | Trends in human-elephant conflict}

There was statistically insignificant increase in reported incidents of property damage $\left(X^{2}=2.53, \mathrm{df}=3, \mathrm{P}=0.46\right)$ and human casualty $\left(X^{2}=3.96, d f=3, P=0.26\right)$ from 2013 to 2016 . Incidents of crop damage dwindled from 2013 to 2014, then increased from 2014 to 2015 and again decreased (Fig. 2). During survey, 67\% of the respondents believed that the trend of HEC is increasing, $18 \%$ believed to be constant and remaining $15 \%$ believed to be decreasing.

\subsection{Spatial pattern of human-elephant conflict}

Negative association $\left(R^{2}=0.43, P=0.001\right)$

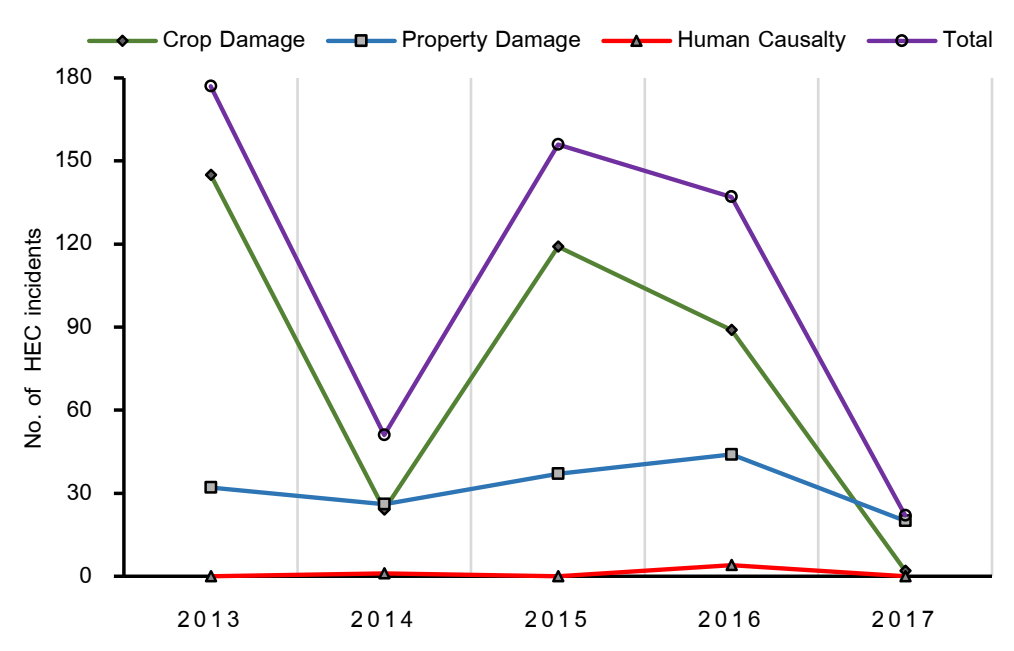

was observed between the conflict incidence and distance of settlement from the nearest forest (Fig. 3). The elephant caused damage incidents decreased with the increase in distance from the forest edges. Among the BZUCs, Ayodhyapuri was the most affected by elephants (Table 1). There was no record of HEC incidents in Kalabanzar, Barandabahar and Khagendramalli from 2013 to 2017. The difference in number of HEC incidents from

Figure 2. Trend of elephant caused damage over years in BZUCs of the CNP 


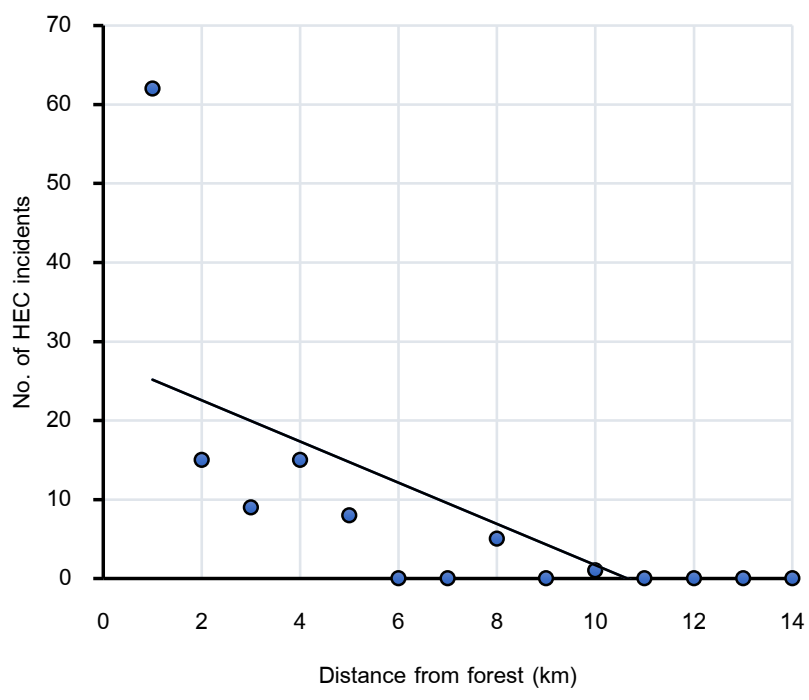

Figure 3. Relation between elephant caused damage incidents and distance from nearest forest $\left(y=-2.60 x+27.78, R^{2}=0.43\right)$.

2013 to 2017, in various BZUCs is statistically significant (ANOVA; df = 12,36; $F=6.93, P<0.01$ )

Table 1. Number of HEC incidents reported in the BZUCs from 2013 to 2016.

\begin{tabular}{|l|l|l|l|l|l|}
\hline \multirow{2}{*}{ Buffer zone } & \multicolumn{4}{|l}{ Year (A.D.) } & Total \\
\cline { 2 - 6 } & $\mathbf{2 0 1 3}$ & $\mathbf{2 0 1 4}$ & $\mathbf{2 0 1 5}$ & $\mathbf{2 0 1 6}$ & \\
\hline Ayodhyapuri & 89 & 17 & 73 & 47 & 226 \\
\hline Bagauda & 14 & 4 & 9 & 26 & 53 \\
\hline Budhi Rapti & 4 & 0 & 0 & 1 & 5 \\
\hline Kerunga & 0 & 0 & 6 & 22 & 28 \\
\hline Lothar & 21 & 9 & 14 & 2 & 46 \\
\hline Megauli & 0 & 0 & 15 & 18 & 33 \\
\hline Mirgakung & 8 & 8 & 17 & 10 & 43 \\
\hline Paanchpandav & 34 & 8 & 2 & 1 & 45 \\
\hline Rewa & 7 & 5 & 20 & 14 & 46 \\
\hline Patihani & 0 & 0 & 0 & 3 & 3 \\
\hline Total & $\mathbf{1 7 7}$ & $\mathbf{5 1}$ & $\mathbf{1 5 6}$ & $\mathbf{1 4 4}$ & $\mathbf{5 2 8}$ \\
\hline
\end{tabular}

\section{4 | Seasonal pattern of conflict}

There was no uniform distribution of the conflict among four study seasons. Crop raiding incidence was significantly higher during post-monsoon season $\left(X^{2}=272.47, \mathrm{df}=3, \mathrm{P}<0.01\right)$ when paddy is ready to harvest (Fig. 4). Property damage was significantly higher during winter season $\left(\chi^{2}=39.191, \mathrm{df}=3, \mathrm{P}<0.01\right)$. Five incidents of human casualty occurred; three deaths, one in winter and two in monsoon season. Two injuries were reported during winter and monsoon. There was no significant relation between the frequency of conflict incidents and average monthly temperature $\left(R^{2}=0.007, P=0.78\right)$ as well with average monthly rainfall $\left(R^{2}=0.008, P=0.78\right)$ (Figure $5 a$ and $\left.b\right)$.

\section{5 | Perception of locals towards elephant}

More than $3 / 4^{\text {th }}$ of the respondents $(77 \%)$ had positive attitude towards the conservation of wild elephants. Among 115 respondents who experienced the HEC during the study period, $72 \%$ were positive, $6 \%$ were neutral and $22 \%$ were negative towards elephant conservation. Whereas, among 275 respondents who didn't experience the HEC during 2013-2016, $79 \%$ were positive, $3 \%$ were neutral and $18 \%$ were negative towards conservation of the elephants. However, there was no significant difference in perception between the HEC victim and non-victim respondents (ANOVA, $d f=1,4 ; F=0.62 ; P=0.47$ ).

Among the respondents who considered elephants to be conserved $(n=300), 40 \%$ regarded elephants as national treasure, $30 \%$ considered elephants as attraction for tourists and income source, $14 \%$ accepted conservation referring to legislative measure of government, $9 \%$ valued elephants as rare species and $7 \%$ considered elephants as lord Ganesh.

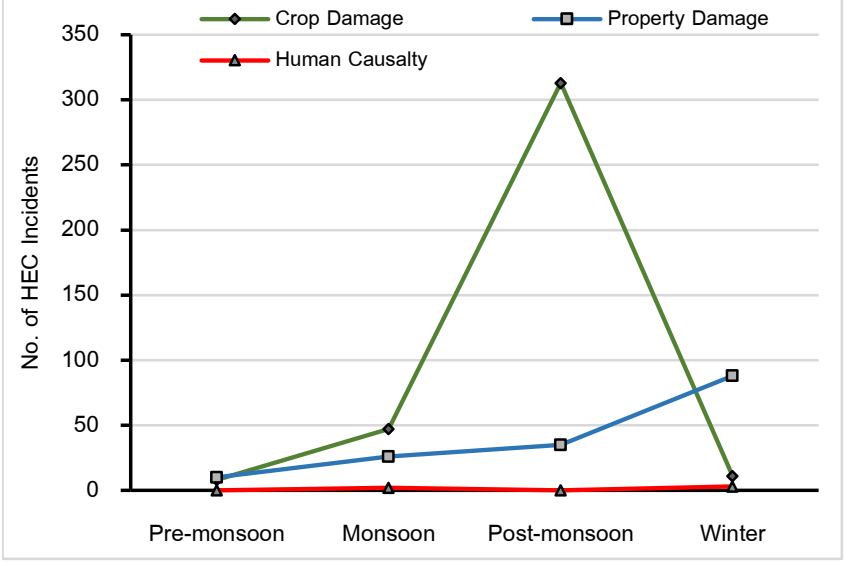

Figure 4. Seasonal pattern of HEC in the buffer zone of CNP.

\section{4 | Discussion}

This study explored the pattern of HEC in the BZUCs of the CNP and revealed that the crop damage is the most common type of harm caused by elephants in the study area followed by property damage and human casualty. Similar results were observed in Eastern Nepal (Shrestha 2007), Western Nepal (Shrestha 2007, Neupane et al. 2018) and entire lowlands of Nepal (Perera 2009, Neupane et al. 2013), India (Wilson et al. 2015, Stone et al. 2019) and Congo (Nsonsi et al. 2018). Elephants raid cropland because natural food in the forest is demanding as a result of increasing 

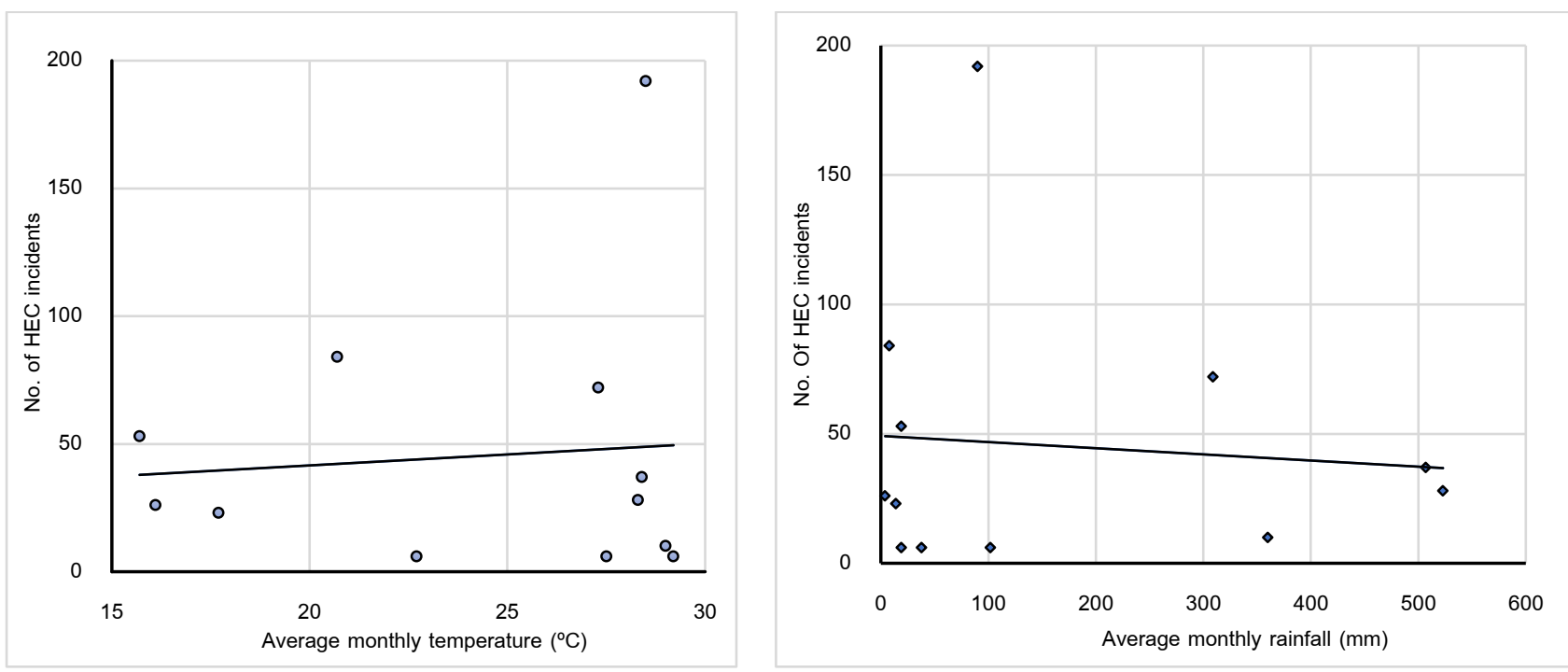

Figure 5. Relation between number of HEC incidents and- a: average monthly temperature $\left(y=0.85 x+24.40, R^{2}=0.007\right)$; $b$ : average monthly rainfall $(y=-0.02 x$ $\left.+40.198, R^{2}=0.008\right)$.

human encroachment and settlement near forest (Chen et al. 2016). Most parts of terai of Nepal were uninhabited by humans until 1950s due to malaria; but after eradication of malaria and government resettlement programs in 1950s, there was rapid human footprint (Pradhan et al. 2011). Hence, encroachment of elephant habitat by humans resulting in increased croplands with palatable food near forest area is one of the precursors of increased crop raiding.

According to Shrestha (2007), Pradhan et al. (2011) and Neupane et al. (2013), the rate of HEC incidents in Nepal is increasing. However, there was no significant trend in increase or decrease of HEC incidents in Chitwan National Park from 2013 to 2016. HEC incidents in Asian countries such as Sri-Lanka, Myanmar, China is increasing both in extent and intensity (Perera 2009, Fernando et al. 2011, Zhang 2011, Das and Mrinmay 2020, Prakash et al. 2020). Elephants are becoming more habituated to conflict as a result, they frequently raid crops and show more aggressive behavior (Fernando et al. 2011, Das \& Mrinmay 2020). Fragmentation of forest and increased population of elephants due to migration from India has been reported to be one of the major causes of inclining HEC in Nepal (Pradhan et al. 2011). But this study didn't reveal such increment in the HEC incidents. This might be because many HEC incidents go unreported due to lengthy official procedures and insufficient and unsatisfying compensation. A study conducted by Lamichhane et al. (2019), also revealed that people from the study area were not satisfied by the current practices of buffer zone. Some HEC incidents such as crop raiding and property damage of smaller scale are tolerated to some extent and are left unreported to the park office (Neupane et al. 2013).

Similarly, villages near to the refuge of elephants experienced large number of HEC incidents in Assam (Wilson et al. 2015). Most crop raiding incidents are observed in croplands near the forest (Naughton-Treves 1998, Sitati et al. 2003, Graham et al. 2010, Chen et al. 2016). But this doesn't mean that elephants forage only at the edges of forest (Naughton-Treves 1998). During dry season when food is scarce in forest, elephants were recorded to travel up to $30 \mathrm{~km}$ to raid crops in southwest of China (Chen et al. 2016). Elephants are attracted by the crops that are closer to the forest because these crops are palatable and nutritious compared to the food in the forest (Sukumar 1992) and conflict will always be higher at the edges of protected areas (Chen et al. 2016). Consistent to those studies, we observed decrease in HEC as the distance from the forest to settlement increased. Similarly, livestock depredation by carnivores were reported to be highest in the villages near to the forest in the study area (Lamichhane et al. 2018). Among the studied BZUCs, the highest number of HEC incidents were observed in Ayodhyapuri BZUC that is consistent to the findings of Pant et al. (2016). The highest number of human kills from wild animals are also observed in this area (Lamichhane et al. 2018). Such a higher prevalence of HEC in Ayodhyapuri might be due to large perimeter of the BZUC adjoining to the CNP forest edge and probable migratory route of elephants.

Crop raiding was the highest during post monsoon season (JuneAugust). Similar results were observed in different parts of Nepal 
(Shrestha 2007, Neupane et al. 2013, Pant et al. 2016, Silwal et al. 2016), Assam (Wilson et al. 2015), Karnataka (Stone et al. 2019) and southern India (Rohini et al. 2016). During postmonsoon season, the palatable and nutritious crops like paddy (Sukumar 1992) are ready to harvest. Additionally, seasonality in crop raiding may be associated with reproduction (Webber et al. 2011). Most Asian bulls comes into musth during winter season and prior to musth, they focus on feeding to improve their body condition (Jainudeen et al. 1972). Although female do not have any seasonal periods of estrus, most of them come into estrus when food availability is higher (Mar 2007). Hence, crop raiding seems to be highest during post-monsoon season because of their reproductive behavior and attraction towards palatable and nutritious food in cropland.

Property damage and human casualty is mostly caused by single bull elephant usually entering villages seeking female captive elephants in estrous cycle (Shrestha 2007) and such bulls in musth are aggressive (Sukumar 2006). Property damage incidents were recorded most during winter season (December to February). Similar results were observed in Nepal (Shrestha 2007, Neupane et al. 2013). According to respondents, wild elephants come to village seeking stored grains, specially rice, salt and sugarcane molasses. Property damage occurs when elephant search for stored grains and liquor (Prakash et al. 2020). Elephants enter human settlement seeking stored grains during winter when food is scarce in forest or in crop lands. Elephants do not intend to damage houses; they are just the consequence of massive elephant searching food products inside the house.

Despite high level of conflict, majority of respondents had positive attitude towards conservation of wild elephants as they regarded elephants as nation's treasure and income source of Nepal. However, respondents who had experienced human casualty by themselves or within their family circle had negative attitude towards conservation of elephants. This could be because people cannot tolerate human casualty as compared to crop damage and property damage. According to Shrestha (2007), majority of people from western Nepal had positive attitude compared to eastern Nepal. Similarly, positive attitude of people towards elephant conservation have been reported from Sri-Lanka, China and India (Fernando et al. 2011, Fernando \& Pastorini 2011, He et al. 2011). In contrast to these, only few people from central Nepal had positive attitude towards the conservation of elephants (Pant et al. 2016). Tolerance to the species also depends on how people cope with the risk they face, people with alternative source of income may tolerate crop raiding better than the subsistence farmers (Treves et al. 2006).

\section{5 | Conclusions}

This study revealed that HEC incidents are increasing in the CNP. The conflict incidents are more frequent at the edges of the park than the distant settlements. Crop damage is the most common type of the HEC and is higher during the paddy harvesting post-monsoon season. Property damage and human casualty incidents are higher in the winter season during which the bulls come to the musth. Despite of increasing trend of HEC, people from BZUCs of the CNP consider elephants to be nation's treasure and are positive towards their conservation. This study confirmed seasonal variation of HEC in the CNP and could be an important baseline information for the conflict mitigation.

\section{Acknowledgements}

We thank Department of National Parks and Wildlife Conservation (DNPWC) and Chitwan National Park Office for granting research permission and providing access to the data. We are grateful to Rupak Maharjan, DNPWC for his support throughout the research. We also thank National Trust for Nature Conservation, Biodiversity Conservation Center, Chitwan for the financial support.

\section{Authors' contributions}

Dangol, D. and Ghimire, A. conceptualized the study. Dangol, D. collected and analyzed the data. Dangol, D. and Ghimire, A. wrote the manuscript. Bhattarai, S. B. supervised the study. All authors contributed in manuscript improvement and gave final approval for publication.

\section{Conflicts of interest}

Authors declare no conflict of interest.

\section{ORCID}

Deepa Dangol (D) https://orcid.org/0000-0001-9200-9894

Anuj Ghimire (D) https://orcid.org/0000-0002-5128-108X

Salina Baskota Bhattarai (D) https://orcid.org/0000-0002-2373-3763

\section{References}

Barnes, R. 1996. The conflict between humans and elephants in the central African forests. Mammal Review 26:67-80. https://doi.org/10.1111/j.1365-2907.1996.tb00147.x

Barnes, R. F. 2008. The design of crop-raiding studies. Gajah 28:4-7 
Campos-Arceiz, A. and Blake, S. 2011. Megagardeners of the forestthe role of elephants in seed dispersal. Acta Oecologica 37:542 553. https://doi.org/10.1016/j.actao.2011.01.014

Chen, Y., Marino, J., Chen, Y., Tao, Q., Sullivan, C. D., Shi, K., et al. 2016. Predicting hotspots of human-elephant conflict to inform mitigation strategies in Xishuangbanna, Southwest China. PLoS ONE 11(9):e0162035. https://doi.org/10.1371/journal.pone.0162035

Choudhury, A., Lahiri Choudhury, D., Desai, A., Duckworth, J., Easa, P., Johnsingh, A., et al. 2008. Elephas maximus. The IUCN Red List of Threatened Species 2008: e.T7140A12828813. https://dx.doi.org/10.2305/IUCN.UK.2008.RLTS.T7140A12828813.en

CNP 2020. Chitwan National Park. https://www.chitwannationalpark.gov.np/index.php. Accessed 16 July, 2020.

Das, C. N. and Mrinmay, M. 2020. Human-elephant confict in Panchet Forest Division, Bankura, West Bengal. Gajah 51:10-15.

Dhakal, B. and Thapa, B. 2019. Residents' perceptions of humanelephant conflict: case study in Bahundangi, Nepal. Environment, Development and Sustainability 21:461-481. https://doi.org/10.1007/s10668-017-0047-1

Distefano, E. 2005. Human-wildlife conflict worldwide: collection of case studies, analysis of management strategies and good practices. Food and Agricultural Organization of the United Nations (FAO), Sustainable Agriculture and Rural Development Initiative (SARDI), Rome, Italy. Available from: http://www.fao.org/documents/card/en/c/e21b6162-b3ad-46618c52-710f95ebeaf7/

DNPWC. 2009. The elephant conservation action plan for Nepal. Department of National Parks and Wildlife Conservation, Kathmandu, Nepal.

DNPWC. 2019. Annual report fiscal year 2077/76. Department of National Parks and Wildlife Conservation, Kathmandu, Nepal.

Fernando, P., Jayewardene, J., Prasad, T., Hendavitharana, W. and Pastorini, J. 2011. Current status of Asian elephants in Sri Lanka. Gajah 35:93-103.

Fernando, P. and Pastorini, J. 2011. Range-wide status of Asian elephants. Gajah 35:15-20.

Goswami, V. R., Vasudev, D. and Oli, M. K. 2014. The importance of conflict-induced mortality for conservation planning in areas of human-elephant co-occurrence. Biological Conservation 176:191-198. https://doi.org/10.1016/j.biocon.2014.05.026

Graham, M. D., Notter, B., Adams, W. M., Lee, P. C. and Ochieng, T. N. 2010. Patterns of crop raiding by elephants, Loxodonta africana, in Laikipia, Kenya, and the management of human elephant conflict. Systematics and Biodiversity 8:435-445. https://doi.org/10.1080/14772000.2010.533716
Haynes, G. 2012. Elephants (and extinct relatives) as earth-movers and ecosystem engineers. Geomorphology 157:99-107. https://doi.org/10.1016/j.geomorph.2011.04.045

He, Q., Wu, Z., Zhou, W. and Dong, R. 2011. Perception and attitudes of local communities towards wild elephant-related problems and conservation in Xishuangbanna, southwestern China. Chinese Geographical Science 21:629. https://doi.org/10.1007/s11769011-0499-4

Hoare, R. 2000. African elephants and humans in conflict: the outlook for co-existence. Oryx 34:34-38. https://doi.org/10.1046/j.13653008.2000.00092.x

ICIMOD. (2013). Land cover of Nepal 2010 [Data set]. ICIMOD. https://doi.org/10.26066/rds.9224

Jainudeen, M., McKay, G. and Eisenberg, J. 1972. Observations on musth in the domesticated Asiatic elephant (Elephas maximus). Mammalia 36:247-261. https://doi.org/10.1515/mamm.1972.36.2.247

Kerley, G. I., Landman, M., Kruger, L., Owen-Smith, N., Balfour, D., De Boer, W., et al. 2008. Effects of elephants on ecosystems and biodiversity. The 2007 scientific assessment of elephant management in South Africa, CSIR, pp 101-147.

Lamichhane, B. R., Persoon, G. A., Leirs, H., Poudel, S., Subedi, N., Pokheral, C. P., et al. 2019. Contribution of buffer zone programs to reduce human-wildlife impacts: the case of the Chitwan National Park, Nepal. Human Ecology 47:95-110. https://doi.org/10.1007/s10745-019-0054-y

Lamichhane, B. R., Persoon, G. A., Leirs, H., Poudel, S., Subedi, N., Pokheral, C. P., et al. 2018. Spatio-temporal patterns of attacks on human and economic losses from wildlife in Chitwan National Park, Nepal. PLoS ONE 13(4): e0195373. https://doi.org/10.1371/journal.pone.0195373

Mar, K. 2007. The demography and life history strategy of timber elephants in Myanmar. PhD Thesis. University College London, UK.

Naughton-Treves, L. 1998. Predicting patterns of crop damage by wildlife around Kibale National Park, Uganda. Conservation Biology 12:156-168. https://doi.org/10.1111/j.1523-1739.1998.96346.x

Neupane, B., Budhathoki, S. and Khatiwoda, B. 2018. Human-Elephant Conflict and Mitigation Measures in Jhapa District, Nepal. Journal of Forest and Livelihood 16:103-112. https://doi.org/10.3126/jfl.v16i1.22885

Neupane, D., Johnson, R. L. and Risch, T. S. 2013. Temporal and spatial patterns of human elephant conflict in Nepal. 2013 International elephant and rhino conservation and research symposium proceedings, 26-30 August 2013, Pittsburgh Zoo and PPG Aquarium.

Nsonsi, F., Heymans, J. C., Diamouangana, J., Mavinga, F. B. and Breuer, T. 2018. Perceived human-elephant conflict and its 
impact for elephant conservation in northern Congo. African Journal of Ecology 56:208-215. https://doi.org/10.1111/aje.12435

Nyhus, P. J. 2016. Human-wildlife conflict and coexistence. Annual Review of Environment and Resources 41:143-171. https://doi.org/10.1146/annurev-environ-110615-085634

Pant, G., Dhakal, M., Pradhan, N. M. B., Leverington, F. and Hockings M. 2016. Nature and extent of human-elephant Elephas maximus conflict in central Nepal. Oryx 50:724-731. https://doi.org/10.1017/S0030605315000381

Perera, B. 2009. The human-elephant conflict: A review of current status and mitigation methods. Gajah 30:41-52.

Pradhan, N. M., Williams, A. C. and Dhakal, M. 2011. Current status of Asian elephants in Nepal. Gajah 35:87-92.

Prakash, T. S. L., Wijeratne, A. and Fernando, P. 2020. Humanelephant conflict in Sri Lanka: Patterns and Extent. Gajah 51:16-25.

Rohini, C., Aravindan, T., Vinayan, P., Ashokkumar, M. and Das, K. A. 2016. An assessment of human-elephant conflict and associated ecological and demographic factors in Nilambur, Western Ghats of Kerala, southern India. Journal of Threatened Taxa 8:89708976. https://doi.org/10.11609/jott.2536.8.7.8970-8976

Shrestha, R. 2007. A case study on human-wildlife conflict in Nepal (With particular reference to Human-Elephant Conflict in Eastern and Western Terai regions). WWF Nepal, Kathmandu, Nepal.

Silwal, T., Kolejka, J. and Sharma, R. 2016. Injury severity of wildlife attacks on humans in the vicinity of Chitwan National Park, Nepal. Journal of Biodiversity Management and Forestry 5:1. https://doi.org/10.4172/2327-4417.1000154

Sitati, N. W., Walpole, M. J., Smith, R. J. and Leader-Williams, N. 2003. Predicting spatial aspects of human-elephant conflict. Journal of Applied Ecology 40:667-677. https://doi.org/10.1046/j.1365-2664.2003.00828.x

Stone, M., Phalke, S., Warren, N., AV, D. K. and Krishnan, A. 2019. Gauging farmers' acceptance of 'social barrier' mechanisms for preventing elephant crop raids. Gajah 50:23-28.

Sukumar, R. 1992. The Asian elephant: ecology and management. Cambridge University Press, Cambridge, UK.

Sukumar, R. 2006. A brief review of the status, distribution and biology of wild Asian elephants Elephas maximus. International Zoo Yearbook 40:1-8. https://doi.org/10.1111/j.1748-1090.2006.00001.x

R Core Team. 2019. R: A language and environment for statistical computing. R Foundation for Statistical Computing. Vienna, Austria. https://www.R-project.org/

Treves, A., Wallace, R. B., Naughton-Treves, L. and Morales, A. 2006. Co-managing human-wildlife conflicts: a review. Human Dimensions of Wildlife 11:383-396. https://doi.org/10.1080/10871200600984265
Webber, C. E., Sereivathana, T., Maltby, M. P. and Lee, P. C. 2011. Elephant crop-raiding and human-elephant conflict in Cambodia: crop selection and seasonal timings of raids. Oryx 45:243-251. https://doi.org/10.1017/S0030605310000335

Wilson, S., Davies, T. E., Hazarika, N. and Zimmermann, A. 2015. Understanding spatial and temporal patterns of human-elephant conflict in Assam, India. Oryx 49:140-149. https://doi.org/10.1371/journal.pone.0210580

WWF. 2005. Human wildlife conflict manual. WWFSARPO Harare, Zimbabwe.

Zhang, L. 2011. Current status of Asian elephants in China. Gajah 35:43-46.

\section{Cite this article as:}

Dangol, D., Ghimire, A. and Bhattarai, S. B. 2020. Humanelephant conflict in the buffer zone of Chitwan National Park, Nepal. Nepalese Journal of Zoology 4(1):36-43. https://doi.org/10.3126/njz.v4i1.30671 